Universidad de Lima

Facultad de Derecho

Carrera de Derecho

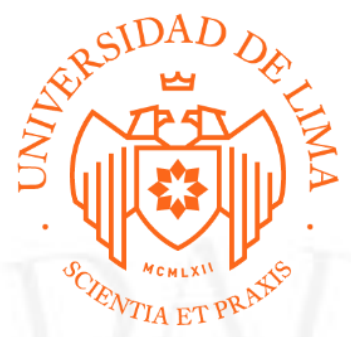

\title{
CIVIL: "RESPONSABILIDAD CIVIL" Y TRIBUTARIO: "IGV"
}

Trabajo de suficiencia profesional para optar el Título Profesional de Abogada

\section{Danixa Giovana Rejas Bejarano}

Código 20121073

Lima - Perú

Junio de 2019 
CIVIL: "RESPONSABILIDAD CIVIL"

Materia: Responsabilidad civil

$\mathrm{N}^{\mathrm{o}}$ de Expediente: 2006-00772 